\title{
Quantitative Resistance to Bean dwarf mosaic virus in Common Bean Is Associated with the Bct Gene for Resistance to Beet curly top virus
}

\author{
P. N. Miklas, USDA-ARS, Vegetable and Forage Crop Research Unit, Prosser, WA 99350; and Y.-S. Seo and \\ R. L. Gilbertson, Department of Plant Pathology, University of California, Davis 95616
}

\begin{abstract}
Miklas, P. N., Seo, Y.-S., and Gilbertson, R. L. 2009. Quantitative resistance to Bean dwarf mosaic virus in common bean is associated with the Bct gene for resistance to Beet curly top virus. Plant Dis. 93:645-648.

The dominant resistance gene, Bct, in common bean (Phaseolus vulgaris) confers qualitative resistance to Beet curly top virus, a leafhopper-transmitted geminivirus in the genus Curtovirus. To determine whether this gene confers resistance to other geminiviruses, bean plants of a recombinant inbred population were sap-inoculated with Bean dwarf mosaic virus (BDMV), a whitefly-transmitted bipartite begomovirus in the genus Begomovirus. Results indicated that Bct (or tightly linked gene) is associated with quantitative resistance to BDMV; thus, the Bct locus is associated with resistance to a bean-infecting begomovirus and curtovirus. The difference in the nature of the resistance to these geminiviruses may indicate a role for minor genes in begomovirus resistance or differences in the virus-host interaction. The Bct locus, whether it acts alone or represents a cluster of tightly linked genes, will be useful in breeding for broad-spectrum begomovirus resistance in common bean.
\end{abstract}

Geminiviruses are the largest group of plant-infecting viruses and cause economically important diseases of vegetable crops, including common bean (Phaseolus vulgaris L.). These viruses are characterized by having twinned icosahedral virions and a circular single-stranded DNA genome (19). The family Geminiviridae is divided into four genera based upon genome structure, host plants infected, and the insect vector. Most bean-infecting geminiviruses are in the genus Begomovirus, which have monopartite or bipartite genomes, infect dicotyledonous hosts, and are transmitted by the whitefly, Bemisia tabaci (Genn.). Members of the genus Curtovirus, which have a monopartite genome, infect dicotyledonous plants, and are transmitted by the beet leafhopper (Circulifer tenellus Baker), also infect common bean and cause curly top disease.

Host resistance can be an effective means of managing diseases of common bean induced by geminiviruses, and progress has been made in mapping a number of the genes involved. The recessive gene,

\section{Corresponding author: P. N. Miklas}

E-mail: phil.miklas@ars.usda.gov

P. N. Miklas and Y.-S. Seo contributed equally to this work.

Accepted for publication 20 February 2009.

doi:10.1094/PDIS-93-6-0645

This article is in the public domain and not copyrightable. It may be freely reprinted with customary crediting of the source. The American Phytopathological Society, 2009. bgm-1, conditions resistance to the begomovirus Bean golden yellow mosaic virus (BGYMV) (28). The bgm-1 gene was located on linkage group B3 near the recessive $b c-1^{2}$ gene, which conditions resistance to Bean common mosaic virus (family Potyviridae, genus Potyvirus) (2). Other genes and QTL for resistance to BGYMV have been characterized: Miklas et al. (13) identified QTL on linkage groups B4 and B7, which derived from the dry bean Dorado; Velez et al. (28) characterized a recessive gene $b g m-2$ derived from breeding line DOR 303; and Osorno et al. (17) discovered two genes, bgm-3 and $B g p-2$, which were introgressed into dry bean from $P$. coccineus. The dominant $B d m$ gene in the pinto bean cv. Othello has been shown to confer resistance to another bean-infecting begomovirus, Bean dwarf mosaic virus (BDMV) (21). An RGA with double Toll/interleukin-1 receptor (TIR) motif (named Phaseolus vulgaris virus response TIR-TIR gene 1 = PvVTT1) was up-regulated in response to BDMV infection in Othello (22). The dominant $B c t$ gene in common bean conditions resistance to the curtovirus Beet curly top virus (BCTV), and is located on linkage group B7 (10) in the vicinity of a QTL associated with moderate resistance to BGYMV $(13,15)$.

There is evidence for genetic linkage of viral resistance genes in crop plants. For example, a genomic region on linkage group 11 in pepper (Capsicum anпиum) possesses a QTL for resistance to Cucumber mosaic virus (CMV, family: Bromoviridae, genus: Cucumovirus) in trans linkage with a dominant gene $L$ for resis- tance to Tobacco mosaic virus (genus: Tobamovirus) (1). These genomic associations of host resistances to distinct viruses suggest the presence of individual resistance genes with broad effect against multiple virus species (23) and/or the presence of resistance gene clusters (9), perhaps formed via gene duplication events with subsequent divergence among genes for specific resistance (11) against different viruses.

In this study, we sought to determine what effect the Bct gene, which conditions resistance to the curtovirus BCTV, may have on infection of common bean by the bipartite begomovirus, BDMV.

\section{MATERIALS AND METHODS}

Plant materials. Ninety-four $\mathrm{F}_{5: 7}$ recombinant inbred lines (RILs) derived by single-seed decent method from a cross between commercial snap bean cultivars Moncayo/Primo were obtained from a previous study. Moncayo is a large flatpodded Romano style snap bean and is highly resistant to BCTV. Primo, with large round pods, is susceptible to BCTV. The 94 RILs were previously characterized for reaction to BCTV, as conditioned by the presence or absence of the Bct resistance gene, across three disease nurseries in the field (10).

BDMV sap-inoculation of common bean plants. For this study, reaction of the same $94 \quad \mathrm{~F}_{5: 7}$ RILs (Moncayo/Primo) to BDMV was determined by sap-inoculation in a growth chamber. Sap inoculum was prepared from young symptomatic leaves collected from BDMV-infected common bean plants (cv. Topcrop) and ground in $0.1 \mathrm{M}$ potassium phosphate buffer $(\mathrm{pH} 8.0)$ with a mortar and pestle. Sap was rubbed onto primary leaves of 7- to 10-day-old common bean plants grown in $14-\mathrm{cm}$ diameter plastic pots (4 plants per pot). Inoculated plants were maintained in a growth chamber $\left(250 \mu \mathrm{mol} \cdot \mathrm{m}^{-2} \cdot \mathrm{s}^{-1}\right.$ photosynthetically active radiation; $16 \mathrm{~h}$ photoperiod: day $30^{\circ} \mathrm{C}$ and night $25^{\circ} \mathrm{C}$ ), and examined for symptoms at 21 days postinoculation (dpi). Eighteen plants of the parents Primo and Moncayo, each RIL, and six individual $F_{1}$ plants, three each from Moncayo/Primo and the reciprocal cross Primo/Moncayo, were sap-inoculated with a single isolate of BDMV from Colombia (8).

Disease evaluation. Individual plants were rated for symptoms using a disease 
severity index (DSI) of 1 to 4 approximately $21 \mathrm{dpi}$, where $1=$ no obvious symptoms; 2 = mild symptoms, no stunted growth, and mild mosaic symptoms on young leaves; 3 = moderate symptoms, stunted growth and obvious leaf curling, and mosaic symptoms beginning in the second to third trifoliolate leaves; and $4=$ severe symptoms, severely stunted growth and leaf curling, and mosaic beginning in the first trifoliolate leaves.

Polymerase chain reaction $(\mathrm{PCR})$ detection of BDMV DNA in leaf tissues. Viral DNA was detected by PCR analysis with the degenerate begomovirus primer pair, PAL1v1978 and PAR 1c496, which directs the amplification of an $\sim 1.1-\mathrm{kb}$ DNA-A fragment (18). DNA was extracted from newly emerged trifoliolate leaves (4) collected from BDMV-infected bean tissues at 21 dpi. PCR conditions were 25 cycles of $94^{\circ} \mathrm{C}, 1 \mathrm{~min} ; 50^{\circ} \mathrm{C}, 2 \mathrm{~min}$; and $72^{\circ} \mathrm{C}, 3 \mathrm{~min}$, and PCR products were analyzed by agarose gel electrophoresis in $1.0 \%$ Tri-borate EDTA buffer.

Statistical analysis. Regression analysis using PROC GLM (20) was used to examine the RIL population (Moncayo/Primo) for association of BDMV reaction as measured by DSI with segregation of the $B c t$ gene conferring resistance to BCTV.

\section{RESULTS}

In preliminary experiments, the response of the snap bean parents, Moncayo and Primo, was assessed by sapinoculation with BDMV. As shown in Table 1, Moncayo showed a high level of resistance (i.e., no obvious disease symptoms and a DSI of 1), whereas Primo was highly susceptible (severe symptoms and a DSI of 4). In PCR tests, no BDMV DNA was detected in leaves of inoculated Moncayo plants, whereas it was detected in all leaves of inoculated Primo plants (data not shown). These results established that Moncayo is highly resistant to BDMV, whereas Primo is highly susceptible.

To gain insight into the genetic nature of the BDMV resistance in Moncayo, six $F_{1}$ plants, three each derived from reciprocal crosses between Moncayo and Primo, were sap-inoculated with BDMV. Five of six plants showed no observable disease symptoms (i.e., DSI of 1), nor was viral DNA detected in these plants by PCR. These results suggest that the BDMV resistance in Moncayo is conditioned as a dominant trait. One $\mathrm{F}_{1}$ plant exhibited mild symptoms in newly emerged trifoliolate leaves (i.e., DSI of 2), and BDMV DNA was detected in symptomatic leaves by PCR (data not shown). This $\mathrm{F}_{1}$ plant was

Table 1. Representative quantitative Bean dwarf mosaic virus (BDMV) reactions for the parents and a subset of recombinant inbred lines (RILs) from a population of $93 \mathrm{~F}_{5: 7}$ RILs (Moncayo/Primo) previously tested for Beet curly top virus (BCTV) reaction in the field (10)

\begin{tabular}{|c|c|c|c|c|c|c|c|}
\hline \multirow[b]{2}{*}{ RIL } & \multirow{2}{*}{$\begin{array}{c}\text { Plants } \\
\text { inoculated }\end{array}$} & \multicolumn{4}{|c|}{$\begin{array}{l}\text { Disease severity index } \\
\text { (DSI) }^{\text {a }} \text { (no. of plants) }\end{array}$} & \multirow[b]{2}{*}{ Mean DSI } & \multirow[b]{2}{*}{ BCTV reaction ${ }^{b}$} \\
\hline & & 1 & 2 & 3 & 4 & & \\
\hline Moncayo & 16 & 16 & & & & 1.0 & $\mathrm{R}$ \\
\hline MP-1 & 16 & 7 & 8 & 1 & & 1.6 & $\mathrm{R}$ \\
\hline MP-5 & 12 & 7 & 4 & 1 & & 1.5 & $\mathrm{R}$ \\
\hline MP-11 & 15 & 14 & 1 & & & 1.1 & $\mathrm{R}$ \\
\hline MP-19 & 14 & & 11 & 3 & & 2.2 & $\mathrm{R}$ \\
\hline MP-26 & 17 & 7 & 6 & 4 & & 1.8 & $\mathrm{R}$ \\
\hline MP-59 & 18 & 18 & & & & 1.0 & $\mathrm{R}$ \\
\hline Primo & 18 & & & & 18 & 4.0 & $\mathrm{~S}$ \\
\hline MP-4 & 14 & & 5 & 4 & 5 & 3.0 & $\mathrm{~S}$ \\
\hline MP-6 & 10 & & & 6 & 4 & 3.4 & $\mathrm{~S}$ \\
\hline MP-55 & 12 & & 3 & 8 & 1 & 2.8 & $\mathrm{~S}$ \\
\hline MP-77 & 7 & 4 & & 3 & & 1.9 & $\mathrm{~S}$ \\
\hline
\end{tabular}

a Symptoms were rated using a DSI of 1 to 4 approximately 21 days postinoculation, where $1=$ no obvious symptoms; 2 = mild, no stunted growth, and mild mosaic symptoms on young leaves; $3=$ moderate, stunted growth and obvious leaf curling, and mosaic symptoms beginning in the 2 nd to 3 rd trifoliolate leaves; and 4 = severe, severely stunted growth and leaf curling, and mosaic beginning in the 1st trifoliolate leaves.

${ }^{\mathrm{b}} \mathrm{R}=B c t$ present, and $\mathrm{S}=B c t$ absent.

Table 2. Summary of Bean dwarf mosaic virus (BDMV) disease reaction as determined by mechanical sap-inoculation for $93 \mathrm{~F}_{5: 7}$ recombinant inbred lines (RILs) (Moncayo/Primo) grouped by $\mathrm{R}$ and $\mathrm{S}$ reaction to Beet curly top virus (BCTV) based on presence and absence of Bct gene, respectively, as determined in previous BCTV disease field trials (10)

\begin{tabular}{|c|c|c|c|c|c|c|c|}
\hline \multirow[b]{3}{*}{ Group } & \multirow{3}{*}{$\begin{array}{l}\text { Total } \\
\text { RILs }\end{array}$} & \multicolumn{6}{|c|}{ Average BDMV reaction (on a per line basis) } \\
\hline & & \multirow{2}{*}{$\begin{array}{l}\text { Avg. } \\
\text { inoculated }^{a}\end{array}$} & \multicolumn{4}{|c|}{$\begin{array}{c}\text { Disease severity index (DSI) } \\
\text { (no. of plants) }\end{array}$} & \multirow{2}{*}{$\begin{array}{l}\text { Mean DSI } \\
\text { rating }\end{array}$} \\
\hline & & & $\mathbf{1}$ & 2 & 3 & 4 & \\
\hline $\mathrm{R}$ to BCTV $-B c t$ & 66 & 13.4 & 8.8 & 4.0 & 0.6 & 0.0 & 1.4 \\
\hline $\mathrm{S}$ to BCTV-bct & 27 & 12.4 & 0.8 & 1.3 & 5.9 & 4.4 & 3.1 \\
\hline
\end{tabular}

a Average number of plants inoculated within a RIL for those RILs with or without the Bct gene.

from a Primo/Moncayo cross with Primo as the female parent; thus it may be derived from a self-pollination.

The $94 \mathrm{~F}_{5: 7}$ RILs sap-inoculated with BDMV showed quantitative disease reactions to BDMV (Table 1). For the 67 RILs with the Bct gene, most inoculated plants had DSI scores of 1 (highly resistant) or 2 (moderately resistant), although some plants within some RILs had DSIs of 3, indicating susceptibility (Tables 1 and 2). Fourteen RILs with $B c t$ had a mean DSI of 1.0 , indicating that all of the plants tested within these lines were highly resistant (i.e., developed no symptoms). For one RIL, MP-97, which possesses Bct and the linked SCAR marker, all inoculated plants developed severe disease symptoms (DSI of 4), indicating a lack of BDMV resistance. This line was retested for reaction to BCTV in the field, and it expressed resistance, as in the previous field tests conducted by Larsen and Miklas (10). An additional 15 plants of MP-97 were sapinoculated with BDMV, and these did not develop symptoms. Therefore, given these contradictory results, RIL MP-97 was omitted from further analyses. Overall, plants in the 66 RILs with $B c t$ had a mean DSI of 1.4, indicating a high level of BDMV resistance (Table 2).

For the 27 RILs that lacked $B c t$, the majority of inoculated plants had DSIs of 3 (moderately susceptible) or 4 (highly susceptible) (Tables 1 and 2). There were some exceptions, e.g., some plants of RIL MP-77 showed a high level of resistance (Table 1). Overall, plants in the RILs without $B c t$ had a mean DSI of 3.1.

Selected plants from RILs with or without $B c t$ and representing the different disease ratings were tested for viral DNA by PCR analysis. Here, BDMV DNA was not detected in plants with a DSI of 1 , whereas viral DNA was detected in plants with DSIs of 2, 3, and 4. Taken together, the viral DNA results and the disease phenotypes for the ratings are consistent with DSIs of 1 and 2 , representing high and moderate levels of resistance, respectively; and DSIs of 3 and 4, representing moderate and high susceptibility, respectively. This agrees with the disease responses and PCR results obtained for the parents Moncayo and Primo.

Regression analysis of the $93 \mathrm{~F}_{5: 7}$ RILs revealed that $77 \%\left(R^{2}\right)$ of the phenotypic variation for mean disease reaction (DSI) to BDMV was explained by presence or absence of the Bct gene $(P<0.0001)$.

\section{DISCUSSION}

Comparison of reactions to BDMV and BCTV in the set of 93 RILs (Moncayo/Primo) clearly indicates that the dominant $B c t$ gene, which conditions resistance to BCTV, is associated with quantitative resistance to BDMV. Other studies have shown co-localization of $\mathrm{R}$ genes and QTL in common bean, but only for resis- 
tance to one pathogen, Colletotrichum lindemuthianum causing bean anthracnose (7), and Pseudomonas syringae pv. phaseolicola causing halo blight (5).

In a previous study of the BCTV reaction in the Moncayo/Primo recombinant inbred population, 67 RILs were resistant and 27 RILs were susceptible (10). In the present study with BDMV, the 66 RILs with $B c t$ exhibited high or moderate levels of BDMV resistance (DSIs 1 or 2), whereas the 27 RILs lacking the gene were moderately or highly susceptible (DSIs 3 or 4). Two RILs did not fit this generalization: MP-19 plants had a mean DSI of 2.2 and possessed $B c t$, whereas MP-77 plants had a mean DSI of 1.9 and lacked Bct. The lack of clear recombination events between the $B c t$ locus and reaction to BDMV suggests that $B c t$ alone conditions the resistance response; however, the small size of the RIL population does not exclude existence of a cluster of linked resistance genes for this locus.

Results of the regression analysis indicate that a single major gene locus $B c t$ explains most of the variation $(77 \%)$ in quantitative reaction to BDMV in the Moncayo/Primo recombinant inbred population, which further supports the hypothesis that this locus or a gene tightly linked to it confers BDMV resistance. However, only 14 RILs with $B c t$ exhibited a high level of resistance (DSI of 1) similar to that of the resistant parent Moncayo. This lack of a high level of resistance in the other RILs with $B c t$ indicates that additional minor genes may be needed to condition the highest levels of resistance. Similarly, only one RIL lacking Bct had a mean DSI of 4.0, similar to the susceptible parent Primo. This result also supports the possibility that minor genes, contributing to the BDMV resistance, are segregating in the population. In the absence of $B c t$, these minor genes appear to provide reduced susceptibility.

The quantitative resistance to BDMV expressed in the Moncayo/Primo recombinant inbred population is different from the qualitative resistance to BDMV conferred by the $B d m$ gene discovered by Seo et al. (21) in the pinto bean cultivar Othello. Inoculation with a BDMV-green fluorescent reporter (GFP) revealed that $B d m$ was involved in blocking long-distance movement of the virus at or near the phloem $(26,29)$. They further demonstrated that germplasm of Andean origin was susceptible to BDMV, whereas most Middle American (MA) germplasm was resistant (Othello is from race Durango of MA origin). The common bean gene pools and designation of races within gene pools are reviewed by Singh et al. (25).

Similarly, most germplasm of Andean origin is susceptible to BCTV (10). Snap beans originate from the Andean gene pool, and many of them possess genes purposely introgressed from the MA gene pool. Moncayo is a snap bean with resis- tance to BCTV, which was achieved by introgression of Bct from the MA gene pool. The Bct gene was originally moved into snap bean via the small white cultivar Burtner, which likely belongs to Race Mesoamerica (24,27). Conversely, purposeful introgression of resistance to BDMV from the MA to the Andean gene pool has not been reported.

The BCTV resistance present in many pinto (including Othello), pink, and great northern cultivars of race Durango derives primarily from the Common Red landrace cultivar $(3,12)$. Many of these same BCTVresistant cultivars (e.g., small red UI-35 and pinto UI-114) exhibited moderate levels of resistance to BGYMV (16) and high levels of resistance to BDMV (21). The resistance to BCTV, BDMV, and BGYMV observed in these Race Durango cultivars could be due to a common gene or cluster of genes.

The Bct gene was mapped to linkage group B7 (10) near a QTL for resistance to BGMYV that was identified in a previous study $(13,15)$. This was one of two QTL for resistance to BGYMV identified in Dorado (DOR 364), a small red cultivar bred for Central America. Dorado was derived primarily from parents of Race Mesoamerica within the MA gene pool. The second QTL was located on B4 within a cluster of genes conditioning resistance to a number of fungal pathogens (14). To date, no other virus resistance gene has been associated with this $\mathrm{R}$ gene cluster. The genomic location of $B d m$ of Race Durango origin on the bean core map $(6,14)$ is unknown.

The genomic association of $B c t$ with a QTL conferring partial resistance to BGYMV, together with the relationship of $B c t$ with quantitative resistance to BDMV observed herein, provides direct evidence for presence of a common locus or gene cluster on linkage group B7 that confers resistance to three distinct geminiviruses, including a curtovirus (BCTV) and two begomoviruses (BDMV and BGYMV). The resistance associated with $\mathrm{B} 7$ is complete for BCTV, but moderate for both BDMV and BGYMV; whereas the resistance observed for the Durango-derived cultivars was high for both BCTV and BDMV and moderate for BGYMV. These differential responses may reflect the different origins for resistance, Mesoamerican in Moncayo and Dorado versus Durango in the pinto, red, and great northern cultivars; or differences in the virushost interaction (30). It would be useful to determine whether $B c t$, as well as $B d m$ and bgm-1, confer resistance to other beaninfecting geminiviruses, given that sources of resistance to these economically important viruses are limited.

\section{LITERATURE CITED}

1. Ben Chaim, A., Grube, R. C., Lapidot, M., Jahn, M., and Paran, I. 2001. Identification of quantitative trait loci associated with resistance to cucumber mosaic virus in Capsicum annuum. Theor. Appl. Genet. 102:1213-1220.

2. Blair, M. W., Rodriguez, L. M., Pedraza, F., Morales, F., and Beebe, S. 2007. Genetic mapping of the bean golden yellow mosaic geminivirus resistance gene $b g m-1$ and linkage with potyvirus resistance in common bean (Phaseolus vulgaris L.). Theor. Appl. Genet. 114:261271.

3. Dean, L. L. 1994. Seventy years of bean research. Annu. Rep. Bean Improv. Coop. 37:911.

4. Dellaporta, S. L., Wood, J. W., and. Hicks, J. B. 1983. A plant minipreparation: Version II. Plant Mol. Biol. Rep. 1:19-21.

5. Fourie, D., Miklas, P. N., and. Ariyarathne, H. M. 2004. Genes conditioning halo blight resistance to races 1,7 , and 9 occur in a tight cluster. Annu. Rep. Bean Improv. Coop. 47:103104.

6. Freyre, R., Skroch, P., Geffroy, W., AdamBlondon, V., Shirmohamadali, A. F., Johnson, W. C., Llaca, V., Nodari, R. O., Pereira, P. A., Tsai, S. M., Tohme, J., Dron, M., Nienhuis, J., Vallejos, C. E., and Gepts, P. 1998. Towards an integrated linkage map of common bean. 4 . Development of a core linkage map and alignment of RFLP maps. Theor. Appl. Genet. 97:847-856.

7. Geffroy, V., Sévignac, M., De Oliveira, J. Fouilloux, G., Skroch, P., Thoquet, P., Gepts, P., Langin, T., and Dron, M. 2000. Inheritance of partial resistance against Colletotrichum lindemuthianum in Phaseolus vulgaris and colocalization of QTL with genes involved in specific resistance. Mol. Plant-Microbe Interact. 13:287-296.

8. Hidayat, S. H., Gilbertson, R. L., Hanson, S. F., Morales, F. J., Ahlquist, P. G., Russell, D. R., and Maxwell, D. P. 1993. Complete nucleotide sequences of the infectious cloned DNAs of bean dwarf mosaic geminivirus. Phytopathology 83:181-187.

9. Hulbert, S. H., Webb, C. A., Smith, S. M., and Sun, Q. 2001. Resistance gene complexes: Evolution and utilization. Annu. Rev. Phytopathol. 39:285-312

10. Larsen, R. L., and Miklas, P. N. 2004. Generation and molecular mapping of a sequence characterized amplified region marker linked with the Bct gene for resistance to Beet curly top virus in common bean. Phytopathology 94:320-325.

11. Michelmore, R. W., and Meyers, B. C. 1998. Clusters of resistance genes in plants evolve by divergent selection and a birth-and-death process. Genome Res. 8:1113-1130.

12. Miklas, P. N. 2000. Use of Phaseolus germplasm in breeding pinto, great northern, pink, and red bean for the Pacific Northwest and intermountain region. Pages 13-29 in: Bean Research, Production and Utilization. Proc. Idaho Bean Workshop. S. P. Singh, ed. University of Idaho, Moscow.

13. Miklas, P. N., Johnson, E., Stone, V., Beaver, J. S., Montoya, C., and Zapata, M. 1996. Selective mapping of QTL conditioning disease resistance in common bean. Crop Sci. 36:13441351.

14. Miklas, P. N., Kelly, J. D., Beebe, S. E., and Blair, M. W. 2006. Common bean breeding for resistance against biotic and abiotic stresses: From classical to MAS breeding. Euphytica 147:105-131.

15. Miklas, P. N., Stone, V., Daly, M. J., Stavely, J. R., Steadman, J. R., Bassett, M. J., Delorme, R., and Beaver, J. S. 2000. Bacterial, fungal, and viral disease resistance loci mapped in a recombinant inbred common bean population ('Dorado'/XAN 176). J. Am. Soc. Hortic. Sci. 125:476-481.

16. Morales, F. J., and Niessen, A. I. 1988. Comparative responses of selected Phaseolus vul- 
garis germ plasm inoculated artificially and naturally with bean golden mosaic virus. Plant Dis. 72:1020-1023.

17. Osorno, J. M., Muñoz, C. G., Beaver, J. S., Ferwerda, F. H., Bassett, M. J., Miklas, P. N., Olczyk, T., and Bussey, B. 2007. Two genes from Phaseolus coccineus L. confer resistance to Bean golden yellow mosaic virus in common bean. J. Am. Soc. Hortic. Sci. 132:530-533.

18. Rojas, M. R., Gilbertson, R. L., Russell, D. R., and Maxwell, D. P. 1993. Use of degenerate primers in the polymerase chain reaction to detect whitefly-transmitted geminiviruses. Plant Dis. 77:340-347.

19. Rojas, M. R., Hagen, C., Lucas, W. J., and Gilbertson, R. L. 2005. Exploiting chinks in the plant's armor: Evolution and emergence of geminiviruses. Annu. Rev. Phytopathol. 43:361-394.

20. SAS Institute Inc. 2004. SAS-OnlineDoc 9.1.3. SAS Institute, Cary, NC.

21. Seo, Y.-S., Gepts, P., and Gilbertson, R. L. 2004. Genetics of resistance to the geminivirus, Bean dwarf mosiac virus, and the role of the hypersensitive response in common bean. Theor. Appl. Genet. 108:786-793.

22. Seo, Y.-S., Jeon, J.-S., Rojas, M. R., and Gilbertson, R. L. 2007. Characterization of a novel Toll/interleukin-1 receptor (TIR)-TIR gene differentially expressed in common bean (Phaseolus vulgaris cv. Othello) undergoing a defence response to the geminivirus Bean dwarf mosaic virus. Mol. Plant Pathol. 8:151162.

23. Seo, Y.-S., Rojas, M. R., Lee, J.-Y., Lee, S.-W., Jeon, J.-S., Ronald, P., Lucas, W. J., and Gilbertson, R. L. 2006. A viral resistance gene from common bean functions across plant families and is up-regulated in a non-virusspecific manner. Proc. Natl. Acad. Sci. USA 103:11856-11861.

24. Silbernagel, M. J., and Jafri, A. M. 1974. Temperature effects on curly top resistance in Phaseolus vulgaris. Phytopathology 64:825827.

25. Singh, S. P., Gepts, P., and Debouck, D. G. 1991. Races of common bean (Phaseolus vulgaris, Fabaceae). Econ. Bot. 45:379-396.

26. Sudarshana, M. R., Wang, H. L., Lucas, W. J., and Gilbertson, R. L. 1998. Dynamics of bean dwarf mosaic geminivirus cell-to-cell and long-distance movement in Phaseolus vulgaris revealed, using the green fluorescent protein. Mol. Plant-Microbe Interact. 11:277-291.

27. Thomas, H. R., and Zaumeyer, W. J. 1953 Developing healthier vegetables. Pages 493508 in: Yearbook of Agriculture, 1953. U.S Dep. Agric

28. Velez, J., Bassett, M. J., Beaver, J. S., and Molina, A. 1998. Inheritance of resistance to bean golden mosaic virus in common bean. $\mathrm{J}$ Am. Soc. Hortic. Sci. 123:628-631.

29. Wang, H. L., Sudarshana, M. R., Gilbertson, R. L., and Lucas, W. J. 1999. Analysis of cellto-cell and long-distance movement of a bean dwarf mosaic geminivirus-green fluorescent protein reporter in host and nonhost species: Identification of sites of resistance. Mol. PlantMicrobe Interact. 12:345-355.

30. Zhou, Y.-C., Garrido-Ramirez, E. R., Sudarshana, M. R., Yendluri, S., and Gilbertson, R L. 2007. The N-terminus of the Begomovirus nuclear shuttle protein (BV1) determines virulence or avirulence in Phaseolus vulgaris. Mol. Plant-Microbe Interact. 20:1523-1534 